DOI: $10.21802 / \mathrm{artm} .2021 .1 .17 .33$.

UDC 616.314-085+616.314-77

\title{
FEATURES OF MANUFACTURE OF ADVANCED PROVISIONAL BRIDGE-BASED PROSTHESES
}

\author{
A.B. Kostyshyn \\ Ivano-Frankivsk National Medical University, Department of Orthopedic Dentistry, \\ Ivano-Frankivsk, Ukraine, \\ ORCID ID: 0000-0001-5500-0874, e-mail: kostushunzorjana1907@gmail.com
}

\begin{abstract}
The relevance of the topic is related to the need to improve methods of preparation of dentitions for orthopedic treatment, taking into account the defects of dentitions in patients with reduced occlusion height, taking into account the condition of the masticatory muscles and temporary use of plastic dentures, which provide gradual lifting of occlusion to normalize the masticatory group muscles and reorganization of myostatic reflexes.

The aim of the research. Improving the effectiveness of preparation for orthopedic treatment of patients with partial tooth loss, with reduced occlusion height, by improving the design of a temporary bridge-based prosthesis.

Materials and methods of research. We examined, treated and conducted clinical observation of 93 patients, who were divided into three groups according to the height of the reduction in occlusion, to achieve this goal and solve problems during the dissertation. Group 1 consisted of 32 patients with included dentition defects with reduced occlusion height up to $2 \mathrm{~mm}(\mathrm{n}=32)$, group 2 - patients with included dentition defects with reduced occlusion height up to 2-4 mm $(n=31)$, group 3 - these are patients with included dentition defects with reduced occlusion height up to 4-6 $\mathrm{mm}(\mathrm{n}=30)$. All patients of the main groups belonged to the second and third age groups according to the WHO, aged 35-55 years. The control group $(\mathrm{n}=30)$ are young people who belonged to the 1st age group according to the WHO with intact dentition, without concomitant somatic and dental pathology, were admitted in one visit. Also, 123 fiberglass-reinforced plastic prostheses were made.
\end{abstract}

Research results. When drawing up a plan for orthopedic treatment of patients with reduced occlusion height, we took into account possible complications, which are characterized by chipping of the facing material, pathological changes in the temporomandibular joint and masticatory muscle group. We have improved the method of manufacturing non-removable temporary plastic orthopedic constructions by reinforcing with fiberglass tapes and beams, to prevent them and gradually raise the bite.

Expanded data on the dynamics of changes in myostatic reflexes and the effectiveness of the use of fixed orthopedic constructions, depending on the pathological process, the timing of adaptation of the masticatory muscle group to orthopedic constructions, according to the degree of reduction in occlusion height. The absence of complaints of breakage and other technical defects of the proposed temporary orthopedic constructions in $100 \%$ of cases, successfully allows to use it in the clinic of orthopedic dentistry.

A new method of preparing patients for permanent orthopedic treatment by combined reinforcement of temporary non-removable bridge constructions with fiberglass tapes and beams is proposed, which differ in that after preliminary modeling of the frame of the bridge constructions, the technology of double reinforcement, model two support platforms with a step-like transition between them, in which fiberglass tapes and beams are fitted with dental tweezers, after which they are polymerized by the generally accepted method with a photopolymer lamp. Complete the modeling of the constructions and polymerize the prosthesis in the pneumopolymerizer with subsequent grinding and polymerize the prosthesis.

Conclusion. The results of the research revealed the high efficiency of the improved method of manufacturing non-removable makeshift plastic of orthopedic constructions.

Keywords: improvements, provisional bridge-based prostheses.

Introduction. In recent years, the number of patients in need of orthopedic treatment has increased due to a decrease in bite height. The prevalence of this disease is up to $40 \%$. Decreased bite height is often accompanied by changes from the side of muscles and nervous system. Insufficient study of muscle condition when drawing up a plan of orthopedic treatment of the patient leads to complications that occur after permanent prosthetics and are characterized by chips of the facing material, pathological changes in the temporomandibular joint, masticatory muscles and circulatory disorders $[1,2]$.
The problem of choosing a method of treatment to reduce the height of the bite, taking into account the condition of the masticatory muscles remains relevant today, because even with the loss of one tooth or poor restoration can cause a slight violation of masticatory function. Accordingly, with the increase of lost teeth, the position of the jaws in space changes and the lower third of the face decreases, there is a violation of the coordination of the masticatory muscles. According to researches by Gavaleshko V.P., such included dentition defects occur in $54 \%$ of dental patients [3], and masticatory efficiency 
depends on the preparation of patients for prosthetics with fixed bridges prostheses [4].

One of the methods of improving the quality of orthopedic treatment with fixed bridges prostheses with reduced bite height, taking into account the condition of the masticatory muscles is the use of provisional fixed constructions that provide a gradual increase in bite height, normalize the condition of the masticatory muscle group, contribute to the restructuring of the "usual" myostatic reflexes, ie restore the functional balance of muscles, teeth, jaws [5]. There are various methods of strengthening the plastic bridge prosthesis: calculation of maximum distances between structural elements: $11 \mathrm{~mm}$ - the length of the intermediate part of the prosthesis, the size of the connector on the vertical and horizontal planes - not less than $4 \mathrm{~mm}$, the minimum thickness of the artificial crown - 1 $\mathrm{mm}$ in the cervical region $1,5 \mathrm{~mm}$ - on the crown belt and $2 \mathrm{~mm}$ - on the chewing surface of the tooth. Reinforcement of both endodontically treated teeth and orthopedic constructions is a reliable way to obtain positive long-term results $[6,7]$. However, the known techniques do not take into account the presence of included defects, reduction of bite height and the need for orthopedic treatment of defects of the dentition in the oral cavity to restore normal bite height.

At the same time the question of comprehensive study of changes of myostatic reflexes during normalization of a bite remains actual and insufficiently studied, decreasing, the terms of adaptation of masticatory muscles and the necessary terms of fixing of temporary constructions in the oral cavity for full functional recovery of the human neuromuscular apparatus after orthopedic treatment have not been set to the end.

Rationale for the research. An urgent issue is the improvement of methods of preparation of the oral cavity for orthopedic treatment with included defects of the dentition with a reduced bite height, taking into account the condition of the masticatory muscles. Therefore, we used temporary plastic teeth prostheses, which provide a gradual increase in bite, to normalize the condition of the masticatory muscle group and the restructuring of myostatic reflexes, improving their design.

The aim of the research. Improving the effectiveness of preparation for orthopedic treatment of patients with partial tooth loss, with reduced bite height, by improving the design of a temporary bridge prosthesis.

Materials and methods of research. We performed orthopedic treatment and further clinical observation of 93 patients, to achieve this goal and solve the tasks. They were divided into three groups. Group 1 consisted of 32 patients with included dentition defects with reduced bite height up to $2 \mathrm{~mm}(\mathrm{n}=32)$, group 2 - patients with included dentition defects with reduced bite height up to $2-4 \mathrm{~mm}(\mathrm{n}=31)$, group 3 - these are patients with included defects of dentitions with the lowered height of a bite to 4$6 \mathrm{~mm}(\mathrm{n}=30)$. All patients of the main groups belonged to the second and third age groups according to the WHO, aged 35-55 years, who require orthopedic treatment with fixed constructions of dentures prostheses. We also examined 30 patients with intact chewing rows, who were the control group. The control group $(n=30)$ are young people who belonged to the 1st age group according to the WHO (age - 18-34 years) with intact dentition row, without concomitant somatic and dental pathology, were admitted in one visit. The survey data were entered into a specially designed survey map, where special attention was paid to the main reason for the decrease in bite height, which was mixed pathological abrasion of the teeth, as well as the bite. Patients had a fixed orthognathic or direct bite, in the anamnesis there were no complaints characteristic of TMJ diseases and bruxism. Patients were admitted for treatment with a diagnosis of a Class III by Kennedy dentition defect. Subjective and objective research methods were used for diagnosis.

Clinical researches have included the improvement of methods of manufacturing a temporary fixed acrylic orthopedic construction, reinforced with fiberglass tapes and beams, according to the method developed by us [8].

Patients were under our observation for 6 months, electromyographic parameters were studied before orthopedic treatment, after fixation of prostheses after 1 week and after 1, 3 and 6 months.

Research results and their discussion. Studying the effect of fixed constructions on the masticatory muscle group, on the example of superficially located m.masseter and m.temporalis, we developed a technology for the manufacture of advanced provisional bridges prostheses, which allowed to study the process of adaptation of the masticatory muscle group to fixed orthopedic constructions, which were kept on the abutment teeth of patients without breakage for 6 months.

The technology of manufacturing advanced provisional bridge prostheses consists of clinical and laboratory stages of manufacturing a plastic bridge prosthesis.

The laboratory stage of modeling and polymerization of the prosthesis is excellent.

Hot polymerization plastic "Sinma $\mathrm{M}+\mathrm{V}$ " ("Stoma", Kharkiv, Ukraine) was used to make this type of bridge prosthesis. Due to the presence of oligomers in plastic, the working time with this material is increased to 1 hour. Thus, before the polymerization process, it is possible not only to properly model the prosthesis, but also to place reinforcing elements in it.

The reinforcing elements in this situation were fiberglass beams (EverStick POST (GC)) and tapes (EverStickPERIO (GC)).

This design was made on the upper or lower jaw of all patients of groups 1 and 2, as well as on both jaws of patients of group 3 . The length was 14 units in the prosthesis. Also indications for the use of this construction may be smaller defects of the dentition row, because the purpose of reinforcement of such construction are the prevention of fracture of fragments of a similar frameless orthopedic construction.

The essence of reinforcement was that after preliminary modeling of the bridge prostheses frame it was prepared according to the rules of preparation of abutment teeth for adhesive bridge prosthesis by double reinforcement technology with fiberglass beams and tapes (Fig. 1). 


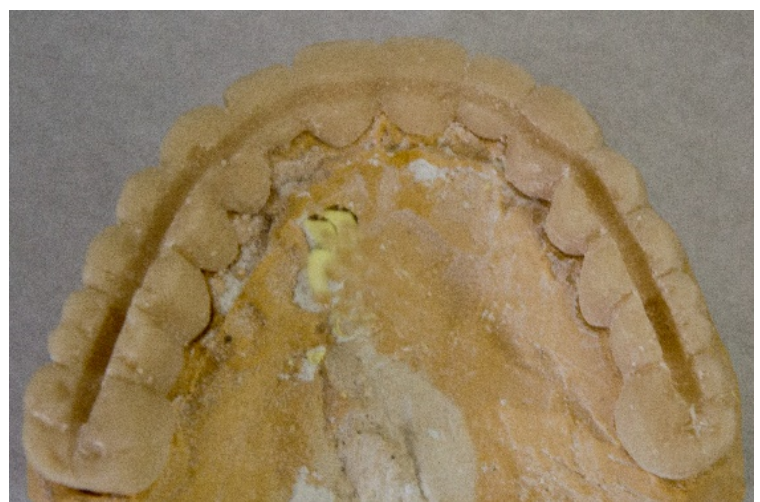

Fig. 1. Prepared bridge prosthesis with grooves for double reinforcement

Thus, two support platforms with a step-like transition between them were modeled, the depth was not more than $2 \mathrm{~mm}$ on the masticatory and proximal surfaces, the width was not more than $1.5-2 \mathrm{~mm}$ (Fig. 2).

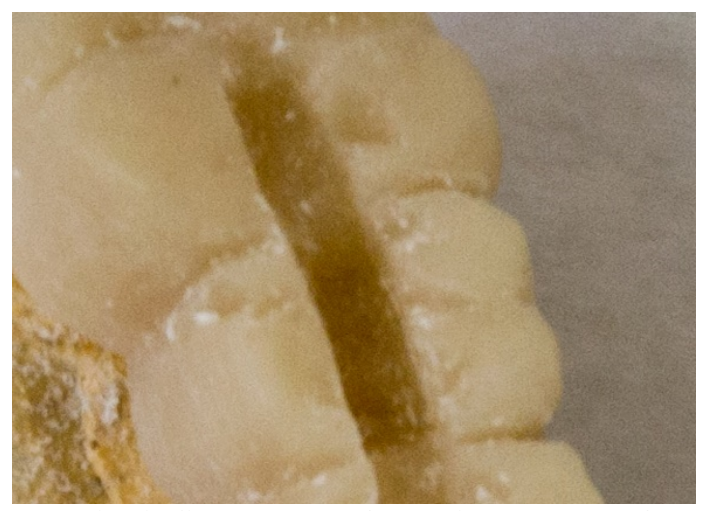

Fig. 2. Support platforms in the area of the defect of the dentition row

The main area ended at the level of the contact point, so as not to break the point contact of the dentition row and so that the material did not touch the gingival papilla, an additional area on the masticatory surface was formed in the projection of the enamel-dentin border of the unprepared tooth to half of the masticatory surface of the tooth in the case of premolars and molars. If the dentition row defect was in the frontal part, we used fiberglass tape reinforcement from the oral surface due to the difficulty of fixation or the need for excessive preparation of abutment

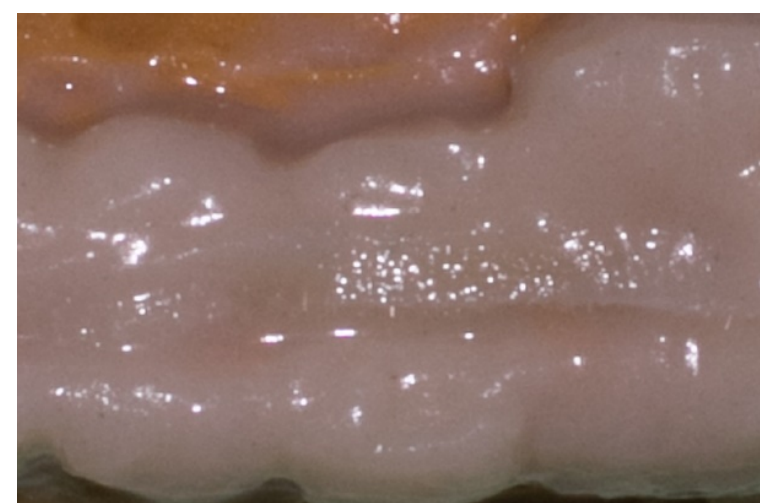

Fig. 5. Applying fiberglass tape on the outer platform of the prosthesis in the lateral area teeth in the case of double reinforcement technology (Fig. 3).

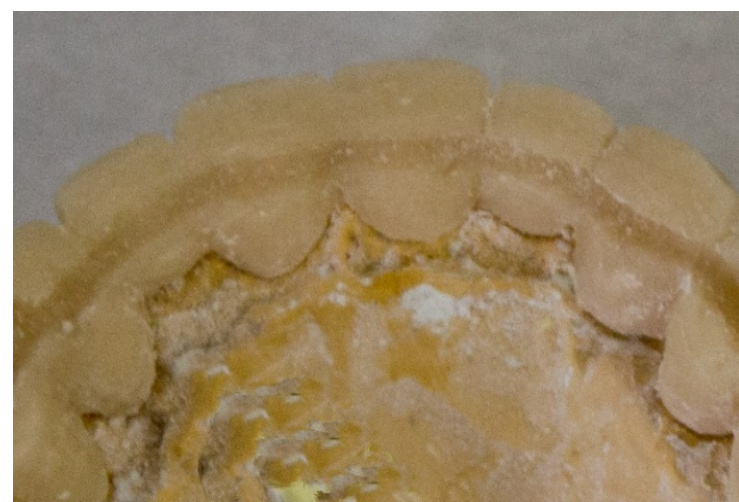

Fig. 3. Prepared grooves for reinforcing elements in the frontal area

Fiberglass reinforcement elements were prepared using a bond- system according to the instructions for use from the manufacturer. They were fitted and placed in the prepared places of the prosthesis frame, after which the final modeling of the bridge-like prosthesis was performed (Fig. 4, Fig. 5, Fig. 6).

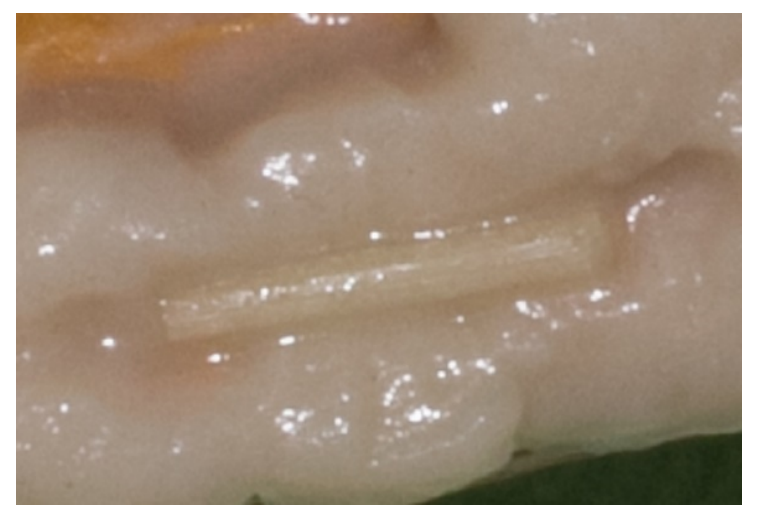

Fig. 4. Fixation of the prepared fragment of the fiberglass beam on the inner platform of the prosthesis in the lateral area

The provisional bridge was polymerized in a dental pneumopolymer for $30 \mathrm{~min}$ at a temperature of $125^{\circ} \mathrm{C}$ and a pressure of 6 Bar.

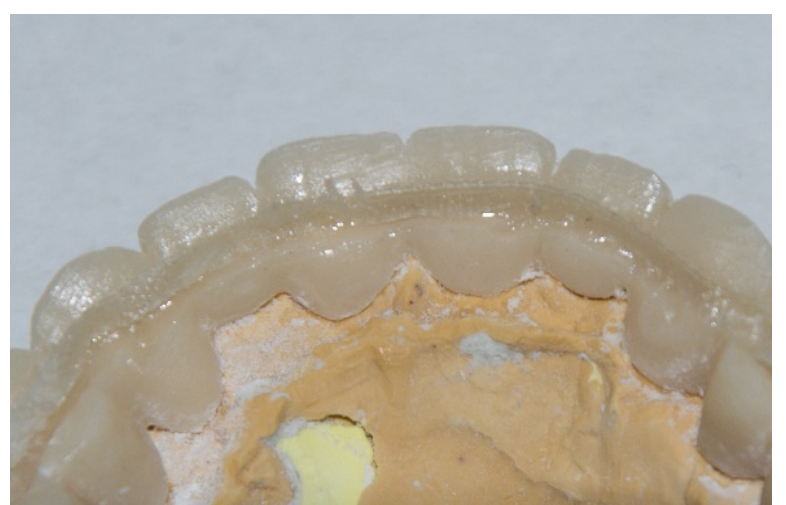

Fig. 6. Applying and fixing fiberglass tape in the frontal area 


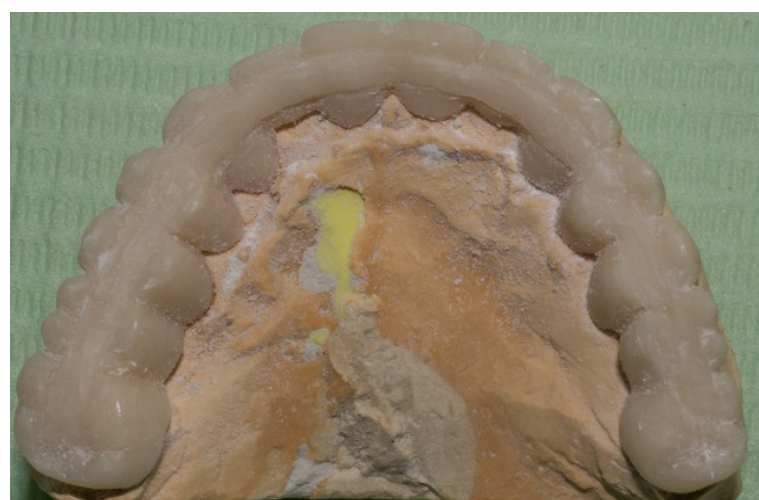

a)

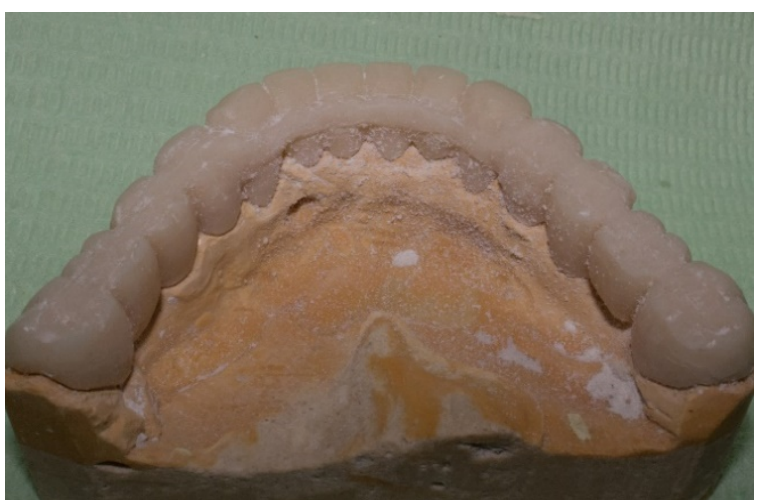

b)

Fig. 7. View of ready unpolished prostheses on the model

After that, the prosthesis was processed, fitted and fixed in the patient's oral cavity (Fig. 7 a, b). The Patent of Ukraine for a utility model № 99089 was obtained for this method [9]. Our patients were made and fixed by provisional bridges prostheses according to an improved method: all persons of groups I and II on one of the jaws, and the subjects of group III on both jaws. Observations were performed after 1 week and 1, 3 and 6 months. All 123 improved bridges prostheses for 6 months functioned without cementation, fracture or other mechanical defects of orthopedic structures, which is a positive result of $100.0 \% \pm 0.0$, and indicates the correct choice of method and materials for their improvement.

The proposed technique is implemented in the clinical practice of the Center of Dentistry of the University Clinic and the Department of Orthopedic Dentistry of Ivano-Frankivsk National Medical University, IvanoFrankivsk Regional Dental Clinic, Ivano-Frankivsk City Dental Clinic, Clinic of the Departments of Dentistry and Postgraduate Education of NMAPE named after P.L.Shupyk, clinics of the Department of Orthopedic Dentistry of the State Institution "Institute of Dentistry of the National Academy of Medical Sciences of Ukraine", clinics of the Departments of the Ukrainian Medical Dental Academy, clinic of the Department of Orthopedic Dentistry of Lviv National Medical University named after Danylo Halytsky.

Conclusions. According to the results of the research, the high efficiency of our improved method of preparing patients for permanent orthopedic treatment was revealed. We have proposed combined reinforcement of temporary fixed bridge constructions with fiberglass tapes and beams, which differs in that after preliminary modeling of the framework of these dentures prostheses, the technology of double reinforcement, model two support platforms with a step-like transition between them, in which fiberglass tapes and beams are fitted with dental tweezers, after which they are polymerized with a photopolymer lamp. The next stage is the modeling of the construction and polymerization of the prosthesis in the pneumopolymerizer, followed by its grinding and polishing.

In order to prevent complications after orthopedic treatment of patients with reduced bite height, we recommended the manufacture of advanced provisional non-removable fiberglass-reinforced plastic orthopedic constructions for a period of 180 days in orthopedic dentistry clinics.
Thus, we have for the first time developed, clinically tested and proved the effectiveness of the method of preparation of dentitions rows for permanent orthopedic treatment with advanced fixed bridges prostheses.

\section{References:}

1. Petrosian MS. Retrospektyvnyi analyz neudach pry nes"emnom protezyrovanyy. Sovremennaia ortopedycheskaia stomatolohyia. 2019; 32:11-14.

2. Makieiev VF, Skalskyi VR, Kyrmanov OS. Vodopohlynannia polimeriv dlia tymchasovoho neznimnoho protezuvannia ta yoho vplyv na mitsni kharakterystyky. Ortopedychna stomatolohiia.2019; 5:87-91.

3. Havaleshko VP. Osoblyvosti protezuvannia defektiv zubnykh riadiv u patsiientiv iz revmatoidnym artrytom. Visnyk problem biolohii i medytsyny. 2019; 1, 2(149):337-40.

4. Nikolov VV, Korol DM, Zaporzhchenko IV, Korol LD. Stan zhuvalnoi efektyvnosti u patsiientiv, yakym provodyly retraktsiiu yasen do protezuvannia neznimnymy zubnymy protezamy. Visnyk problem biolohii i medytsyny. 2018; 2(144):369-372.

5. Raman P. Physiologic neuromuscular dental paradigm for the diagnosis and treatment of temporomandibular disorders. J.Calif. Dent. Ass. 2014; 42(8):563-71.

6. Vasilenko R. Sravnitelnue fiziko-mekhanicheskie i prochnostnue kharakterystiki armirovannukh i nearmirovannukh polnukh semnukh plastinochnukh protezov verkhnei cheliusti. Sovremennaia stomatolohyia. 2015; 3:94-97.

7. Pavlychko RR, Dydyk NM. Prychyny vynyknennia uskladnen pislia armuvannia zubiv shtyftovymy konstruktsiiamy za rezultatamy viddalenykh klinichnykh sposterezhen. 2015; 3-4:138-139.

8. Kostyshyn AB, Rozhko MM, Kostyshyn ZT, Pelekhan LI, Kinash IO. Sposib armuvannia na mezhi «Koronka-Fasetka» plastmasovykh mostopodibnykh proteziv. Patent Ukrainy na korysnu model № 98135. 2015; Kvit, 27.

9. Kostyshyn AB, Rozhko MM, Pelekhan LI, vynakhidnyky; IFNMU, patentovlasnyk. Sposib kombinovanoho armuvannia tymchasovykh neznimnykh ortopedychnykh konstruktsii za dopomohoiu sklovoloknnykh balok ta strichok. Patent Ukrainy na korysnu model № 99089. 2015; Trav, 10. 


\section{УДК 616.314-085+616.314-77 \\ ОСОБЛИВОСТІ ВИГОТОВЛЕННЯ УДОСКОНАЛЕНИХ ПРОВІЗОРНИХ МОСТОПОДІБНИХ ПРОТЕЗІВ}

\section{А.Б. Костишин}

\author{
Івано-Франківський національний медичний \\ університет, кафедра ортопедичної стоматології, \\ м. Івано-Франківськ, Украӥна, \\ ORCID ID: 0000-0001-5500-0874, \\ e-mail: kostushunzorjana1907@gmail.com
}

Резюме. Актуальність теми пов'язана 3 необхідністю вдосконалення методів підготовки ротової порожнини до ортопедичного лікування при включених дефектах зубних рядів у пацієнтів зі зниженою висотою прикусу.

Мета дослідження. Підвищення ефективності підготовки до ортопедичного лікування пацієнтів із частковою втратою зубів, при зниженій висоті прикусу, шляхом удосконалення конструкції тимчасового мостоподібного протеза.

Матеріали й методи дослідження. Для досягнення поставленої мети та вирішення завдань обстежено й проліковано, проведено клінічне спостереження 93 пацієнтів, виготовлено 123 пластмасові, армовані скловолокном незнімні протези.

Результати дослідження. При складанні плану ортопедичного лікування пацієнтів зі зниженою висотою прикусу враховано можливі ускладнення, які характеризуються сколами облицювального матеріалу, патологічними змінами в скроневонижньощелепному суглобі та жувальній групі м'язів. Для їх запобігання та поетапного підняття прикусу нами вдосконалена методика виготовлення провізорних пластмасових ортопедичних конструкцій за рахунок армування скловолоконними стрічками та балками та ефективність використання незнімних зубних протезів, у залежності від патологічного процесу, встановлено терміни адаптації жувальної групи м'язів до ортопедичних конструкцій, відповідно до ступеню зниження висоти прикусу.

Відсутність скарг на поломки та дефекти при використанні удосконалених мостоподібних протезів у 100 \% випадків дозволяє рекомендувати їх у роботу клінік ортопедичної стоматології.

Висновки. За результатами дослідження виявлено високу ефективність удосконаленої методики виготовлення незнімних провізорних пластмасових ортопедичних конструкцій.

Ключові слова: удосконалення, провізорні мостоподібні протези.

\section{УДК 616.314-085+616.314-77 \\ ОСОБЕННОСТИ ИЗГОТОВЛЕНИЯ УСОВЕРШЕНСТВОВАННЫХ ПРОВИЗОРНЫХ МОСТОВИДНЫХ ПРОТЕЗОВ}

\author{
А.Б. Костишин
}

Ивано-Франковский национальный медиџинский университет, кафедра ортопедической стоматологии, г. Ивано-Франковск, Украина, ORCID ID: 0000-0001-5500-0874. e-mail: kostushunzorjana1907@gmail.com

Резюме. Актуальность темы связана с необходимостью совершенствования методов подготовки полости рта к ортопедическому лечению при включенных дефектах зубных рядов у пациентов с пониженной высотой прикуса.

Цель исследования. Повышение эффективности подготовки к ортопедическому лечению пациентов с частичной потерей зубов, при пониженной высоте прикуса, путем усовершенствования конструкции временного мостовидного протеза.

Материалы и методы исследования. Для достижения поставленной цели обследовано, проведено лечение и наблюдение 93 пациентов, изготовлено 123 пластмассовые армированные стекловолокном несъемные протезы.

Результаты исследования. При составлении плана ортопедического лечения пациентов с пониженной высотой прикуса учитывали возможные осложнения, характеризующиеся сколами облицовочного материала, патологическими изменениями височно-нижнечелюстного сустава и жевательной группы мышц. Для их предотвращения и поэтапного поднятия прикуса мы усовершенствовали методику изготовления провизорных пластмассовых ортопедических конструкций за счет армирования стекловолоконными лентами и балками, и эффективность использования несъемных зубных протезов, в зависимости от патологического процесса, установлены сроки адаптации жевательной группы мышщ к ортопедическим конструкциям, соответственно степени снижения высоты прикуса.

Отсутствие жалоб на поломки и дефекты при использовании временных мостовидных протезов в $100 \%$ случаев позволяет рекомендовать ее в работу клиник ортопедической стоматологии.

Выводы. По результатам исследования выявлена высокая эффективность усовершенствованной методики изготовления несъемных провизорных пластмассовых ортопедических конструкций.

Ключевые слова: усовершенствование, провизорные мостовидные протезы. 